\title{
Carboxy derivatives of isoflavones as affinity carriers for cytotoxic drug targeting in adrenocortical H295R carcinoma cells
}

\author{
D Somjen, N Stern, E Knoll, O Sharon, B Gayer ${ }^{1}$, T Kulik ${ }^{1}$ \\ and $\mathbf{F}$ Kohen ${ }^{1}$
}

Institute of Endocrinology, Metabolism and Hypertension, Tel-Aviv Sourasky Medical Center and the Sackler Faculty of Medicine, Tel-Aviv, Israel

${ }^{1}$ Department of Biological Regulation, Weizmann Institute of Science, Rehovot, Israel

(Requests for offprints should be addressed to F Kohen; Email: fortune.kohen@weizmann.ac.il)

\begin{abstract}
Carboxy derivatives of isoflavones that exhibit oestrogenic/anti-oestrogenic properties were used as carriers for affinity drug targeting to H295R adrenocortical carcinoma cells that express transcripts of oestrogen receptor (ER) $\alpha$ and $\beta$. These derivatives were prepared by introducing a carboxymethyl group at the 6-position of genistein and of biochanin $\mathrm{A}$, yielding $6 \mathrm{CG}$ and $6 \mathrm{CB}$ respectively. In transactivation assays, 6CG displayed mixed agonist/antagonist activity for $\mathrm{ER} \alpha$, whereas $6 \mathrm{CB}$ displayed only weak antagonist activity. Low concentrations of oestrogen, 6CG and 6CB were capable of inducing proliferation in H295R cells and of stimulating creatine kinase (CK) specific activity, suggesting that these cells were sensitive to oestrogenic compounds. In in vivo experiments, both 6CG and 6CB were capable of inhibiting oestrogen-induced $\mathrm{CK}$ specific activity in rat tissues. For affinity drug targeting, the cytotoxic drug daunomycin was coupled to $6 \mathrm{CB}$ and $6 \mathrm{CG}$, yielding 6CB-Dau and 6CG-Dau respectively. These conjugates were tested for their antiproliferative ability to inhibit
\end{abstract}

DNA synthesis as assessed by incorporation of $\left[{ }^{3} \mathrm{H}\right]$ thymidine in H295R cells. A dose-dependent cytoxicity was observed with both conjugates. At 0.3-3 nM, both conjugates were 10 to 30 times more potent than daunomycin. At $30 \mathrm{nM}$ these conjugates were two to three times more potent than daunomycin. At concentrations ranging between 300 and $3000 \mathrm{nM}$, no difference in cytotoxicity was observed between the conjugates and daunomycin. When the cells were treated over a wide range of concentrations with a combination of 6CG plus daunomycin, the observed cytotoxicity was less than with daunomycin alone. When non-transformed rat enterocytes, which do not express ER, were treated with 6CG-Dau or daunomycin, the antiproliferative effect of 6CG-Dau was the same as that of daunomycin over the concentration range tested. These pilot studies suggest that the ready availability of oestrogenic binding sites in H295R cells can be exploited for site-directed chemotherapy.

Journal of Endocrinology (2003) 179, 395-403

\section{Introduction}

The human H295R adrenocortical carcinoma cell line possesses all the major adrenocortical enzyme systems (e.g. P450 scc, 450c17, P450c21, aromatase etc) (Gazdar et al. 1990, Staels et al. 1993). In recent years this cell line has been used as a model system to study the induction and inhibition of steroidogenic enzymes by a variety of compounds such as oestrogen (Gell et al. 1998), phytoestrogens (Ohno et al. 2002) and pesticides (Sanderson et al. 2002). In these cells, oestrogen at high concentrations (1$10 \mu \mathrm{mol} / \mathrm{l}$ ) inhibited cortisol synthesis by specifically inhibiting the activity of the $3 \beta$ hydroxysteroid dehydrogenase enzyme (Gell et al. 1998). In addition, high concentrations of the phytoestrogens, daidzein and genistein, stimulated the production of dehydroepi- androsterone sulphate and decreased cortisol synthesis by suppressing P450s21 enzymatic activity (Mesiano et al. 1999).

Several studies have indicated that oestrogens and phytoestrogens (Kurzer \& Xu 1997) can act as growth modulators in various cell types. To date, no studies on the effects of low doses of either oestrogen or phytoestrogen derivatives on the oestrogenic response of these cells in terms of DNA synthesis and creatine kinase (CK) specific activity have been reported. It was therefore of interest to explore the sensitivity of these cells to low concentrations of oestrogenic compounds.

In a previous study, we have described the properties of 6-carboxymethyl genistein (6CG) (Somjen et al. 2002), synthesized in our laboratory. Interestingly, in human vascular smooth muscle cells, 6CG and oestrogen 
stimulated DNA synthesis at a low concentration $(0.3 \mathrm{nmol} / \mathrm{l})$. Moreover, 6CG displayed antagonist activities when oestrogen was bound to oestrogen receptor (ER) $\alpha$ but not ER $\beta$. Biochanin A is a derivative of genistein having a methoxy group at position $4^{\prime}$. In several cell systems, biochanin A can be converted to genistein (Peterson et al. 1998). As an extension of our previous work, we describe here the synthesis and evaluation of 6-carboxymethyl biochanin A (6CB) as an agonist/ antagonist of oestrogen action in vitro and in vivo. In addition, we evaluate the effects of oestrogen, 6CG and $6 \mathrm{CB}$ on $\left[{ }^{3} \mathrm{H}\right]$ thymidine synthesis and $\mathrm{CK}$ specific activity in H295R cells; in pilot studies we have observed that these cells were sensitive to oestrogenic stimulation. Moreover, H295R cells expressed transcripts of ER $\alpha$ and ER $\beta$. Taking these facts into consideration, we prepared cytotoxic isoflavone-daunomycin conjugates of $6 \mathrm{CG}$ and $6 \mathrm{CB}$ for the selective delivery of cytotoxic drugs to H295R cells that express ER. Our results indicate that the isoflavonedaunomycin conjugates in H295R cells were more potent than daunomycin alone, and caused inhibition of cell proliferation at concentrations much lower than that required with the free daunomycin.

\section{Materials and Methods}

\section{Reagents}

All reagents were of analytical grade. Chemicals and kits for CK determination were purchased from Sigma ( $\mathrm{St}$ Louis, MI, USA). Biochanin A was purchased from Indofine Chemical company (Somerville, NJ, USA) and purified by alumina column chromatography before use. Methyl- $\left[{ }^{3} \mathrm{H}\right]$ thymidine $(5 \mathrm{Ci} / \mathrm{mmol})$ and $\left[{ }^{3} \mathrm{H}\right]$ oestradiol $(85 \mathrm{Ci} / \mathrm{mmol})$ were obtained from New England Nuclear (Boston, MA, USA). Baculovirus-expressed recombinant ER $\alpha$ and ER $\beta$ preparations were from Panvera (Madison, WI, USA). Streptavidin-coated plates were from Wallac (Turku, Finland). Cy3.5 Bis reactive dye was purchased from Amersham Pharmacia Biotech (Buckinghamshire, $\mathrm{UK})$.

\section{Cells}

Human adrenocortical cancer cells (NCI-H295R) were from ATTC (Rockville, MD, USA) and were grown according to the instructions of ATTC. Cells were grown to subconfluence and then treated with various hormones or agents as indicated. Non-tranformed rat enterocytes (IEC cells), used as control, were obtained from Professor $\mathrm{N}$ Arber, Ichilov Hospital, Tel-Aviv, and grown as described previously (Arber et al. 1996).

\section{Preparation of carboxy derivatives of isoflavones}

6-CG (Kohen et al. 1999) (compound I, Fig. 1) was prepared as previously described. 6-CB (compound II,

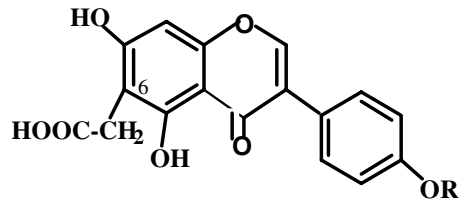

I: $\mathrm{R}=\mathrm{H}, 6-$ Carboxymethyl genistein

II: $\mathrm{R}=\mathrm{Me}, 6-\mathrm{Carboxymethyl}$ biochanin $\mathrm{A}$

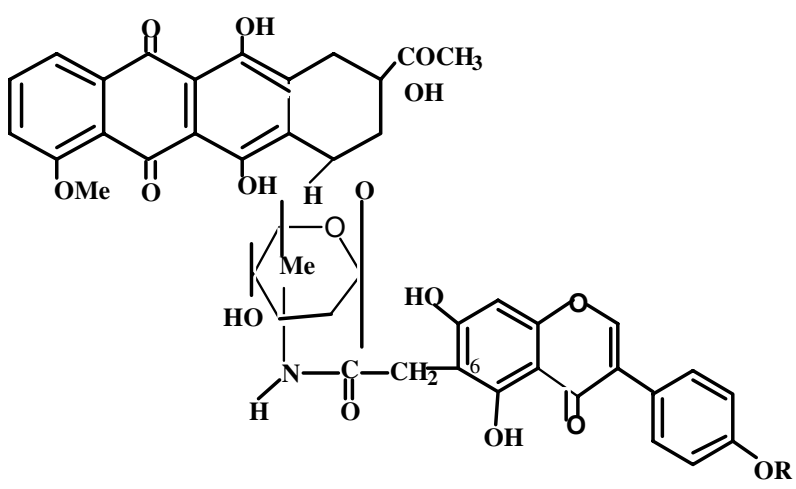

III: $\mathrm{R}=\mathrm{H}$, genistein-daunomycin conjugate $\mathrm{IV}: \mathrm{R}=\mathrm{Me}$, biochanin A-daunomycin conjugate

Figure 1 Structures of carboxy derivatives of isoflavones, 6-carboxymethyl genistein and 6-carboxymethyl biochanin A, and their respective daunomycin conjugates.

Fig. 1) was prepared as follows: sodium $(0 \cdot 31 \mathrm{~g})$, cut into small pieces, was added under nitrogen to a three-necked flask containing $n$-propanol $(8 \mathrm{ml})$. After dissolution of sodium, purified biochanin A $(100 \mathrm{mg})$ in $6 \mathrm{ml} n$-propanol was added. The reaction mixture was stirred for $15 \mathrm{~min}$ and bromoacetic acid $(0.377 \mathrm{~g})$ in $2 \mathrm{ml} n$-propanol was added. A precipitate was formed immediately, and the colour of the reaction changed gradually from yellow to green. The reaction mixture was stirred for $2 \mathrm{~h}$ at $60{ }^{\circ} \mathrm{C}$ and then cooled to room temperature. Water was added and the solvent was evaporated. The residue was acidified with $5 \mathrm{~N} \mathrm{HCl}$ to $\mathrm{pH} 3$ and extracted with ether. The organic phase was washed with water, separated, dried with anhydrous magnesium sulphate, evaporated and chromatographed on Silica gel 60. Elution of Silica gel 60

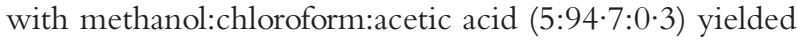
the desired mono-addition product $(20 \mathrm{mg})$ with an $\mathrm{R}_{\mathrm{f}}$ of $0 \cdot 5$ in the solvent system chloroform:methanol:acetic acid (89.7:10:0.3); biochanin A showed an $\mathrm{R}_{\mathrm{f}}$ of $0 \cdot 8$. The $\left[{ }^{1} \mathrm{H}\right] \mathrm{NMR}$ spectrum of this carboxy derivative of biochanin A (compound II, Fig. 1) in deuterated dimethyl sulphoxide showed the following signals: $\delta: 8 \cdot 3(1 \mathrm{H}, 2-\mathrm{H})$, 
$7 \cdot 46\left(2 \mathrm{H}, \mathrm{d}, J=2 \mathrm{~Hz}, 2^{\prime} \mathrm{H}\right.$ and $\left.6^{\prime} \mathrm{H}\right), 6 \cdot 97(2 \mathrm{H}, \mathrm{d}, J=2 \mathrm{~Hz}$, $3^{\prime} \mathrm{H}$ and $\left.5^{\prime} \mathrm{H}\right), 6 \cdot 28(1 \mathrm{H}, \mathrm{s}, 8-\mathrm{H}), 3 \cdot 6\left(2 \mathrm{H}, \mathrm{s},-\mathrm{CH}_{2^{-}}\right.$ $\mathrm{COOH})$ and $3.74(3 \mathrm{H}, \mathrm{s}, \mathrm{OMe})$. The NMR spectrum of this compound did not have a doublet at $\delta 6 \cdot 20$, which is attributed to $8-\mathrm{H}$ in genistein (Kohen et al. 1999) and biochanin A, indicating that the carboxymethyl group was introduced at position 6 of biochanin A.

\section{Synthesis of isoflavone-daunomycin conjugates}

6CG and 6CB were conjugated to daunomycin in a two-step procedure. As an example for the synthesis of cytotoxic isoflavone conjugates, we describe here the preparation of the 6CG-daunomycin conjugate.

6CG (compound I, Fig. 1) (3.76 mg) was dissolved in dry dioxane $(366 \mu \mathrm{l})$. N-Hydroxysuccinimide $(2 \cdot 2 \mathrm{mg})$ and carbodiimide $(2.9 \mathrm{mg})$ were then added, and the reaction mixture was left overnight at room temperature. The reaction mixture was then analysed by thin layer chromatography using $\mathrm{CHCl}_{3}: \mathrm{MeOH}$ :acetic acid (84.75:15:0.25) as the developing solvent, and an $\mathrm{R}_{\mathrm{f}}$ of 0.95 was obtained, indicating that the active ester of $6 \mathrm{CG}$ was formed. In the same solvent system, 6CG showed an $\mathrm{R}_{\mathrm{f}}$ of $0 \cdot 4$.

Daunomycin $(0.8 \mathrm{mg})$ was dissolved in $20 \mu \mathrm{l} 0 \cdot 13 \mathrm{M}$ $\mathrm{NaHCO}_{3}$. A portion of the active ester prepared above $(110 \mu \mathrm{l})$ was then added dropwise, and the reaction mixture was stirred overnight at $4{ }^{\circ} \mathrm{C}$. The $\mathrm{pH}$ of the reaction mixture was subsequently adjusted to 8 . The desired conjugate product, 6CG-Dau (compound III, Fig. 1), was isolated by ethyl acetate extraction of the reaction mixture. The organic phase was then separated from the aqueous phase, dried with magnesium sulphate and evaporated. The concentration of the conjugate was then determined at $495 \mathrm{~nm}$ using an absorption coefficient $(\varepsilon)$ of 10000 . The electron mass spectrum of this compound gave the expected molecular weight of 859.90, corresponding to $\mathrm{C}_{44} \mathrm{H}_{39} \mathrm{NO}_{16} \mathrm{Na}$.

The 6CB-Dau conjugate (compound IV, Fig. 1) was prepared using the same reaction conditions as for the 6CG-Dau conjugate.

\section{Receptor binding assays}

The relative binding activities of the carboxy derivatives of isoflavones to ER proteins were assessed using recombinant ER $\alpha$ or ER $\beta$ proteins, streptavidin-coated plates, $\left[{ }^{3} \mathrm{H}\right]$ oestrogen $(3 \mathrm{nM})$ and biotinylated anti-ER antibodies (100 ng/well) as described previously (Somjen et al. 2002). The concentration of oestrogen in the receptor assay ranged from $0 \cdot 1$ to $100 \mathrm{nM}$, whereas the concentration of the competitors in the assay ranged from $10 \mathrm{nM}$ to $1 \mu \mathrm{M}$. Stock concentrations $(1 \mathrm{mM})$ of the carboxy isoflavones were made in DMSO. Subsequently, for the receptor assay, dilutions were made in binding buffer. Concentrations of the competitors greater than $1 \mu \mathrm{M}$ were not used, because the receptor assay could be performed with a concentration of DMSO $<0 \cdot 1 \%$.

\section{Preparation of total RNA}

Total RNA from H295R cells was extracted using the TRIzol reagent (Gibco Life Technologies) according to the manufacturer's instructions.

\section{$R T-P C R$}

Total RNA $(1 \mu \mathrm{g})$ was subjected to reverse transcription using the BD Advantage One-Step RT-for PCR kit from BD Biosciences Clontech (Palo Alto, CA, USA). For ER $\alpha$, we used $5 \mu \mathrm{l}$ cDNA in the reaction mixture with the primers 5'-AATTCTGACAATCGACGCCAG-3' (forward) and 5'-GTGCTTCAACATTCTCCCTCC TC-3' (reverse), for 30 cycles at $94^{\circ} \mathrm{C}$ for $30 \mathrm{~s}$, at $57^{\circ} \mathrm{C}$ for $30 \mathrm{~s}$ and at $72^{\circ} \mathrm{C}$ for $1 \mathrm{~min}$. For $\mathrm{ER} \beta$, the same amount of cDNA was used with the primers $5^{\prime}$-TGCTTT GGTTTGGGTGATTGC-3' (forward) and 5'-TTTGC TTTTACTGTCCTCTGC-3' (reverse) for 30 cycles at $94{ }^{\circ} \mathrm{C}$ for $30 \mathrm{~s}$, at $58{ }^{\circ} \mathrm{C}$ for $30 \mathrm{~s}$ and at $72{ }^{\circ} \mathrm{C}$ for $1 \mathrm{~min}$. Plasmids pRST7ER $\alpha$ and pRST7ER $\beta$ (kindly provided by Dr D McDonnell, Durham, NC, USA) served as positive controls in these reactions.

\section{Transfection and luciferase assay}

The transcriptional activity of the carboxy isoflavone derivatives relative to oestradiol was determined in vitro as described previously (Somjen et al. 2002). Briefly, MCF7 human breast cancer cells (ATTC) were transfected with a 3 xERE-TATA-Luc reporter plasmid, from Dr B van der Burg (Utrecht, the Netherlands) and Renilla phRL (Promega). After transfection and incubation with the various stimulants was completed, the luciferase activity of each well was determined using the dual Luciferase system (Stop and Glow; Promega) and a luminometer (M2010; Lumac, Landgraaf, Holland).

\section{Assessment of DNA synthesis}

Cells were grown until subconfluence using conditions described previously (Somjen et al. 1998) and then treated with various hormones or agents for 24 or $48 \mathrm{~h}$ as indicated. At the end of incubation, $\left[{ }^{3} \mathrm{H}\right]$ thymidine was added for $2 \mathrm{~h}$. Cells were then treated with $10 \%$ ice-cold trichloroacetic acid (TCA) for $5 \mathrm{~min}$ and washed twice with 5\% TCA and then with cold ethanol. The cellular layer was dissolved in $0.3 \mathrm{ml} 0.3 \mathrm{M} \mathrm{NaOH}$, aliquots were taken for counting radioactivity, and $\left[{ }^{3} \mathrm{H}\right]$ thymidine incorporation into DNA was calculated.

\section{Creatine kinase extraction and assay}

In vitro studies Cells were treated for $24 \mathrm{~h}$ with various hormones and agents as specified. CK specific activity was determined as described previously (Somjen et al. 1998). 


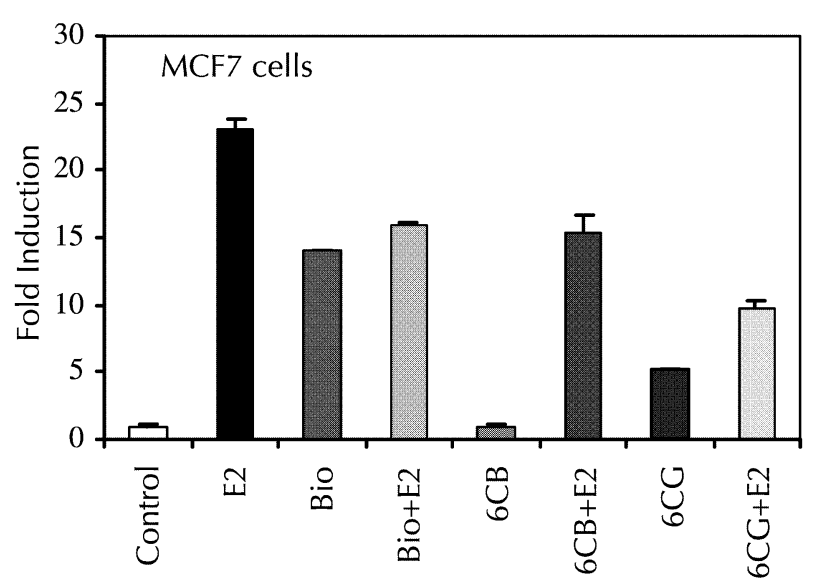

Figure 2 Transcriptional activity of ER $\alpha$ with oestrogen (E2), biochanin A (Bio), 6-carboxymethyl biochanin A (6CB) and 6-carboxymethyl genistein (6CG). MCF7 human breast cancer cells were transfected with two plasmids consisting of 3 xERE-TATA-Luc reporter and Renilla luciferase. The cells were then treated with oestrogen $\left(10^{-9} \mathrm{M}\right)$, Bio $(1 \mu \mathrm{M})$, 6CG $(1 \mu \mathrm{M}), 6 \mathrm{CB}$ $(1 \mu \mathrm{M})$ or combinations of Bio E2, E2 +6CG or E2 $+6 \mathrm{CB}$. Firefly luciferase activity was measured $24 \mathrm{~h}$ later. Luciferase activity was standardized to the internal co-transfected Renilla activity and expressed as the ratio of induced activity to the activity in the absence of ligand. Each data point represents the mean \pm S.D. of triplicates of three different experiments.

In vivo studies Changes in $\mathrm{CK}$ specific activity in the epiphyseal cartilage, diaphyseal bone, uterus, aorta and left ventricle of the heart, induced by the $24 \mathrm{~h}$ treatment with oestrogen $(5 \mu \mathrm{g})$, biochanin A $(0.5 \mathrm{mg}), 6 \mathrm{CB}(250 \mu \mathrm{g})$, biochanin A $(0.5 \mathrm{mg})$ plus oestrogen $(5 \mu \mathrm{g})$ or $6 \mathrm{CB}$ $(250 \mu \mathrm{g})$ plus oestrogen $(5 \mu \mathrm{g})$ were studied in 25 -day-old Wistar-derived immature female rats, using five animals in a group. Rats injected intraperitoneally (i.p.) with $0 \cdot 05 \%$ DMSO in PBS served as controls. The dose of oestrogen used for each rat was $5 \mu \mathrm{g}$, because this dose is optimal for skeletal tissue. The rats were killed by decapitation $24 \mathrm{~h}$ after i.p. injection. The various organs were removed and stored at $-20{ }^{\circ} \mathrm{C}$ until processed for $\mathrm{CK}$ activity as described previously (Somjen et al. 1998). All experiments were carried out according to the regulations of the committee for experimental animals of the Weizmann Institute of Science.

\section{Statistical analysis}

The significance of differences between the mean values obtained from experimental groups and controls was evaluated by the unpaired two-tailed Student's $t$-test and by analysis of variance.

\section{Results}

\section{Oestrogen receptor binding studies}

In binding assays, carried out as described previously (Somjen et al. 2002), the relative binding affinity of 6CG, relative to oestradiol which was set arbitrarily to $100 \%$, to ER $\beta$ was $0 \cdot 1 \%$; that to $\mathrm{ER} \alpha$ was $<0.01 \%$. In contrast, $6 \mathrm{CB}$ at concentrations of $1 \mathrm{nM}$ to $1 \mu \mathrm{M}$ did not inhibit the binding of $\left[{ }^{3} \mathrm{H}\right]$ oestradiol to $\mathrm{ER} \beta$ or to $\mathrm{ER} \alpha$.

\section{Transcriptional activity of carboxy isoflavone analogues}

The transactivation activities of $6 \mathrm{CG}$ and $6 \mathrm{CB}$ were measured after incubation of transfected MCF7 cells with biochanin $\mathrm{A}(1 \mu \mathrm{M})$ with or without carboxy isoflavone analogues $(1 \mu \mathrm{M})$ in the absence or presence of oestrogen $(1 \mathrm{nM})$. Only 6CG showed moderate agonistic activity, and $6 \mathrm{CB}$ had no effect in these cells. In the presence of oestrogen, both compounds displayed moderate antagonist activity for ER $\alpha$ (Fig. 2). Biochanin A showed agonistic activity and did not stimulate or inhibit the agonistic effect of oestradiol (Fig. 2). Tamoxifen $(1 \mu \mathrm{M})$ had negligible

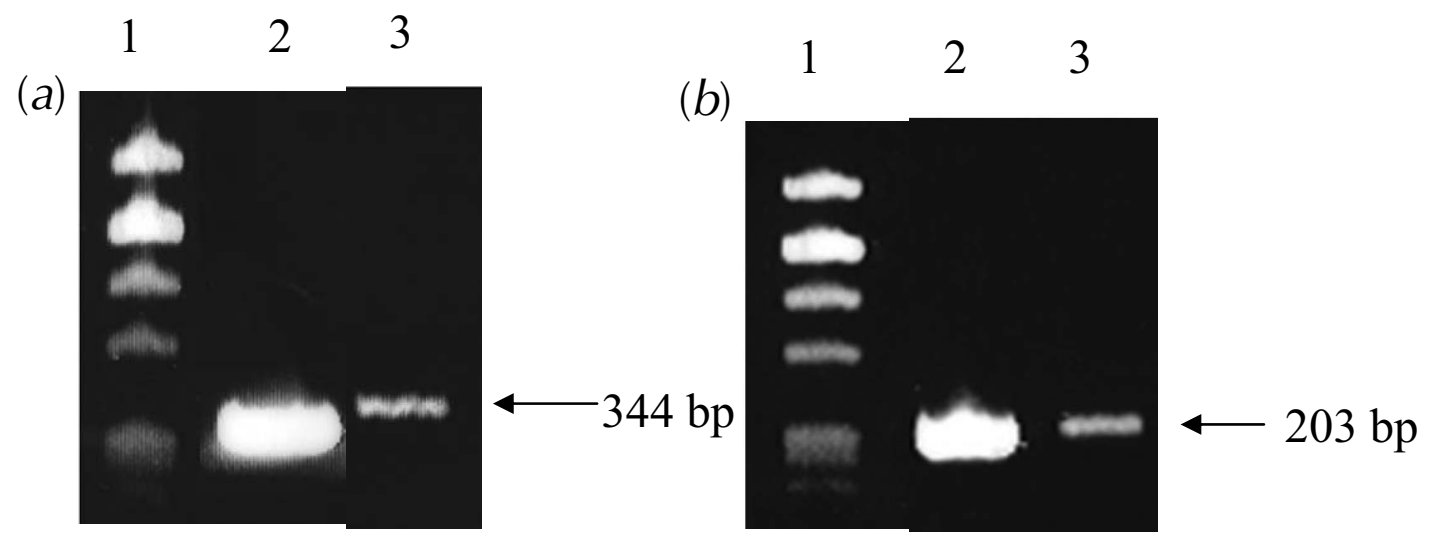

Figure 3 Expression of mRNAs encoding (a) ER $\alpha$ and (b) ER $\beta$ in H295R cells using reverse transcriptase PCR. (a) Amplified fragments: lane 2, positive control (ER 344 bp); lane 3, H295R cells. (b) Amplified fragments: lane 2, positive control (ER 203 bp); lane 3, H295R cells. 

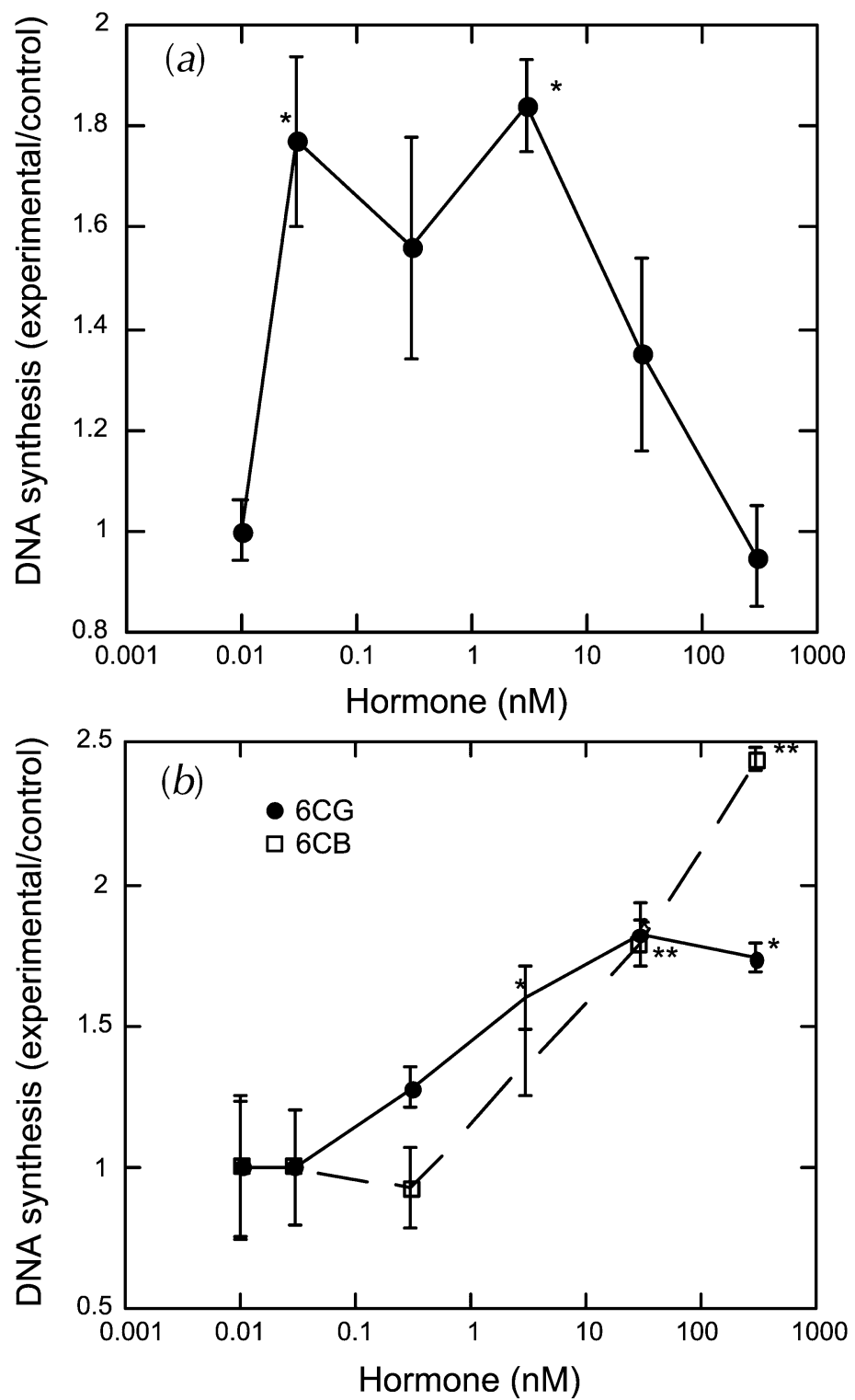

Figure 4 Effect of (a) oestrogen and (b) 6CG and 6CB on DNA synthesis as assessed by $\left[{ }^{3} \mathrm{H}\right]$ thymidine incorporation in H295R cells. Results are means \pm S.E.M. of 8-16 incubates from 2-4 experiments and are expressed as the ratio between $\left[{ }^{3} \mathrm{H}\right]$ thymidine incorporation in hormone-treated and control cells. ${ }^{*} P<0.05,{ }^{*} P<0.01$ compared with baseline.

transcriptional activity. In the presence of oestrogen, tamoxifen blocked the transcriptional activity of oestrogen to basal levels (data not shown).

Expression of oestrogen receptor isoforms $E R \alpha$ and $E R \beta$ in H295R cells

Figure 3 depicts RT-PCR products of mRNA extracted from cultured H295R cells with specific primers for either
ER $\alpha$ and ER $\beta$. As shown, both oestrogen receptor isoforms are expressed in cultured H295R cells.

Effects of oestrogenic compounds on $\left.{ }^{3} H\right]$ thymidine incorporation and CK specific activity in vitro in $H 295 \mathrm{R}$ cells

Oestrogen at very low concentrations $(0 \cdot 03-3 \mathrm{nmol} / \mathrm{l})$ stimulated $\left[{ }^{3} \mathrm{H}\right]$ thymidine incorporation in these cells. Greater concentrations of oestrogen $(>30 \mathrm{nmol} / \mathrm{l})$ had no 
Table 1 Dose-dependent effects of oestrogen on creatine kinase (CK) specific activity in H295R cells. Results are means \pm S.E.M. of 8-16 incubates from 2-4 experiments and are expressed as the ratio between the specific activities of creatine kinase in hormone-treated and control cells

\begin{tabular}{ll} 
& \multicolumn{1}{c}{$\begin{array}{l}\text { CK specific } \\
\text { activity ratio }\end{array}$} \\
\cline { 2 - 2 } $\begin{array}{l}\text { Dose of } \\
\text { oestrogen }(\mathrm{nM})\end{array}$ \\
0 & \\
$0 \cdot 03$ & $1 \cdot 00 \pm 0 \cdot 16$ \\
$0 \cdot 3$ & $1 \cdot 09 \pm 0 \cdot 11$ \\
3 & $1 \cdot 27 \pm 0 \cdot 13$ \\
30 & $1 \cdot 43 \pm 0 \cdot 15^{*}$ \\
300 & $1 \cdot 68 \pm 0 \cdot 19^{*}$ \\
3000 & $2 \cdot 03 \pm 0 \cdot 12^{* *}$ \\
& $1 \cdot 88 \pm 0 \cdot 22^{*}$ \\
\hline$* P<0 \cdot 05, * * P<0 \cdot 01$ compared with no oestrogen.
\end{tabular}

significant effect on DNA synthesis (Fig. 4a). Dosedependent stimulation of DNA synthesis was also observed with the carboxy isoflavones 6CB and 6CG (Fig. 4b).

Oestrogen stimulated CK activity in a dose-related manner, reaching a plateau at $30 \mathrm{nmol} / 1$ (Table 1). Raloxifene $(3 \mu \mathrm{M})$ showed no effect on either DNA synthesis or CK specific activity in these cells, and also did not block oestrogen-, 6CB- or 6CG-driven stimulation (data not shown). CK specific activity was increased by 6CG (30 nmol/l: $148 \pm 12 \% ; 300 \mathrm{nmol} / \mathrm{l}: 174 \pm 10 \%)$ and by $6 \mathrm{CB}(100 \mathrm{nmol} / \mathrm{l}: 240 \pm 5 \%)$. The combination of oestrogen $(30 \mathrm{nmol} / \mathrm{l})$ and $6 \mathrm{CB}(100 \mathrm{nmol} / \mathrm{l})$ did not have an additive or inhibitory effect on CK activity in these cells (oestrogen alone: $264 \pm 24 \%$; 6CB +oestrogen: $236 \pm$ $34 \%)$. Control, unstimulated cells were arbitrarily set at $100 \pm 12 \%$.
Stimulation of the specific activity of CK by biochanin A analogues in vivo

In immature female rats, oestradiol $(5 \mu \mathrm{g} / \mathrm{rat})$ and biochanin A $(0.5 \mathrm{mg} / \mathrm{rat})$ stimulated the CK specific activity in all the rat tissues that were examined (uterus, pituitary, epiphysis, diaphysis, aorta and left ventricle of the heart; Table 2), whereas 6CB $(250 \mu \mathrm{g} / \mathrm{rat})$ increased the CK specific activity in all the rat tissues with the exception of the uterus. The stimulatory response of oestrogen to CK specific activity was inhibited in all the tissues when rats were treated with a combination of oestrogen plus $6 \mathrm{CB}$, suggesting that $6 \mathrm{CB}$ acts like a selective oestrogen receptor modulator (SERM) in these tissues (Table 2).

\section{Cytotoxicity studies of isoflavone-daunomycin conjugates in cultured cells}

The cytotoxicity of isoflavone-daunomycin conjugates in H295R cells was tested after $48 \mathrm{~h}$ of incubation using incorporation of $\left[{ }^{3} \mathrm{H}\right]$ thymidine as a marker of proliferation. At low concentrations $(0 \cdot 3-3 \mathrm{nM})$, both conjugates (i.e. 6CG-Dau and 6CB-Dau) were 10-30-fold more toxic than daunomycin. At $30 \mathrm{nM}$, the conjugates were still two to three times more toxic than daunomycin. At high concentrations $(300-3000 \mathrm{nM})$, these conjugates showed the same toxicity as daunomycin. Moreover, when H295R cells were treated with a combination of 6CG plus daunomycin, the net effect was less than that seen with daunomycin alone, thus suggesting that 6CG partially prevented the cytotoxic effects of daunomycin at the entire range of concentrations tested $(0 \cdot 3-3000 \mathrm{nM}$; Fig. 5a). In contrast, when IEC cells, which are devoid of functional ER, were treated with daunomycin or 6CG-Dau conjugate, no difference in cytotoxicity was observed between the free daunomycin and the cytotoxic isoflavone conjugate over a wide range of concentrations (Fig. 5b).

Table 2 Stimulation of the specific activity of creatine kinase by oestrogen and isoflavone derivatives in rat tissues in vivo. Immature female rats were injected with $0.5 \mathrm{ml}$ saline containing $0.5 \%$ DMSO (C, control) oestradiol (E2, $5 \mu \mathrm{g} / \mathrm{rat}$ ), biochanin A (Bio, $0.5 \mathrm{mg} / \mathrm{rat}), 6$-carboxymethyl biochanin A (6CB, $0.25 \mathrm{mg} / \mathrm{rat}$ ), oestradiol $(5 \mu \mathrm{g} / \mathrm{rat})$ plus Bio $(0 \cdot 5 \mathrm{mg} / \mathrm{rat})(\mathrm{Bio}+\mathrm{E} 2)$ or oestradiol $(5 \mu \mathrm{g} / \mathrm{rat})$ plus $6 \mathrm{CB}(0 \cdot 25 \mathrm{mg} / \mathrm{rat})(6 \mathrm{CB}+\mathrm{E} 2)$. Organs were assayed for creatine kinase activity $24 \mathrm{~h}$ after treatment. The results are expressed as means \pm S.D. for $n=5$ rats and further expressed as experimental over control where the control is given a value of $1 \cdot 0$

\begin{tabular}{|c|c|c|c|c|c|c|}
\hline & $\mathrm{C}$ & E2 & Bio & $6 C B$ & Bio +E2 & $6 C B+E 2$ \\
\hline \multicolumn{7}{|l|}{ Organ } \\
\hline Epiphysis & $1 \pm 0 \cdot 09$ & $1 \cdot 85 \pm 0 \cdot 16^{*}$ & $2 \cdot 38 \pm 0 \cdot 18^{* *}$ & $1 \cdot 61 \pm 0 \cdot 17^{*}$ & $2 \cdot 09 \pm 0 \cdot 19^{* *}$ & $1 \cdot 02 \pm 0 \cdot 29$ \\
\hline Diaphysis & $1 \pm 0 \cdot 16$ & $2 \cdot 75 \pm 0 \cdot 23^{* *}$ & $1 \cdot 9 \pm 0 \cdot 24^{*}$ & $1.51 \pm 0.05^{*}$ & $2 \cdot 78 \pm 0 \cdot 13^{* \star}$ & $0 \cdot 84 \pm 0 \cdot 07$ \\
\hline Uterus & $1 \pm 0 \cdot 11$ & $1 \cdot 49 \pm 0 \cdot 13^{*}$ & $1 \cdot 42 \pm 0 \cdot 13^{*}$ & $0 \cdot 89 \pm 0 \cdot 12$ & $1 \cdot 48 \pm 0 \cdot 11^{*}$ & $1 \cdot 02 \pm 0 \cdot 22$ \\
\hline Aorta & $1 \pm 0 \cdot 1$ & $2 \cdot 43 \pm 0.06^{* *}$ & $2 \pm 0 \cdot 18^{* *}$ & $1 \cdot 63 \pm 0 \cdot 11^{*}$ & $2 \cdot 38 \pm 0 \cdot 06^{* *}$ & $1 \cdot 33 \pm 0 \cdot 15$ \\
\hline Left ventricle & $1 \pm 0.09$ & $1 \cdot 53 \pm 0 \cdot 13^{*}$ & $1 \cdot 42 \pm 0.04^{*}$ & $1 \cdot 91 \pm 0 \cdot 16^{*}$ & $1 \cdot 6 \pm 0.09^{*}$ & $1 \cdot 1 \pm 0 \cdot 12$ \\
\hline Pituitary & $1 \pm 0 \cdot 14$ & $1 \cdot 45 \pm 0.05^{*}$ & $1 \cdot 58 \pm 0.05^{*}$ & $1.54 \pm 0.05^{*}$ & $1 \cdot 66 \pm 0 \cdot 14^{*}$ & $1 \cdot 16 \pm 0 \cdot 08$ \\
\hline
\end{tabular}

${ }^{*} P<0 \cdot 05,{ }^{* *} P<0 \cdot 01$, treated compared with control. 

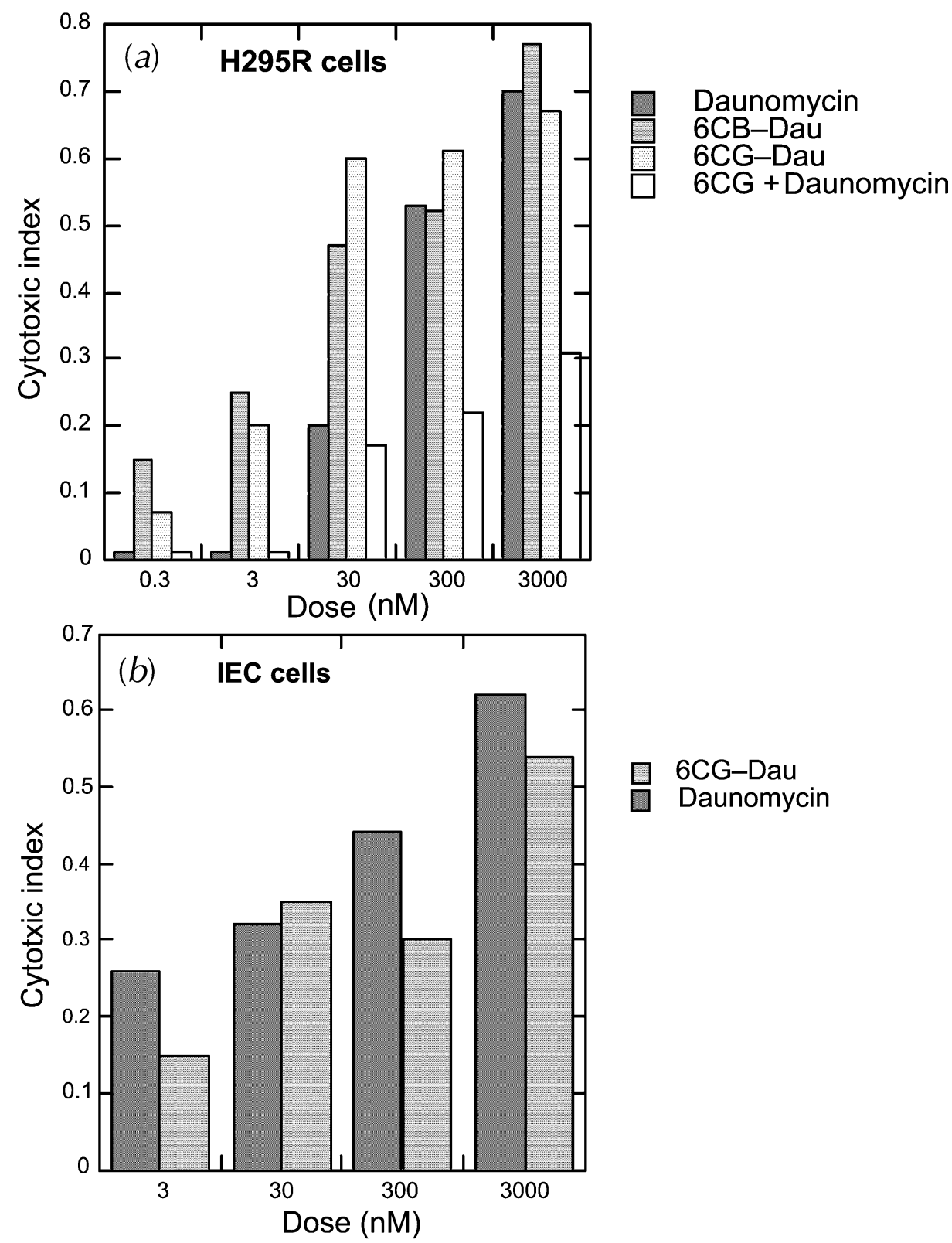

Figure 5 Toxicity of isoflavone-daunomycin conjugates in H295R and IEC cells. (a) H295R cells were treated with varying doses of daunomycin, 6-carboxymethyl biochanin A-daunomycin conjugate (6CB-Dau), 6-carboxymethyl genistein-daunomycin conjugate (6CG-Dau) or a combination of 6CG plus daunomycin, and assayed for $\left[{ }^{3} \mathrm{H}\right]$ thymidine incorporation. The cytotoxic index is shown on the $y$-axis. (b) IEC cells were treated with varying doses of daunomycin or 6CG-daunomycin conjugate and assayed for $\left[{ }^{3} \mathrm{H}\right]$ thymidine incorporation. The cytotoxic index is shown on the $y$-axis. Results are means of three experiments.

\section{Discussion}

Our main goal in this study was to use H295R adrenocortical carcinoma cells as a model system for affinity targeting of cytotoxic drugs (e.g. daunomycin) linked to a carrier that could be preferentially recognized by mem- branal or nuclear steroid receptors present in these cells. For this purpose, we first established that H295R cells express nuclear ER $\alpha$ and $\operatorname{ER} \beta$ (Fig. 3) and most probably membranal ER (unpublished results). Moreover, these cells are sensitive to low doses of oestrogen in terms of proliferation (Fig. 4a) and in terms of stimulating CK 
activity (Table 1). We then chose a carrier that exhibits oestrogenic and anti-oestrogenic properties and contains a reactive group (carboxy) that is able to react with the primary amino group of the sugar moiety of daunomycin. A derivative of genistein, 6-carboxymethyl genistein (6CG), synthesized in our laboratory fulfilled these requirements. In addition to $6 \mathrm{CG}$, we explored the possibility of using another carboxy isoflavone as carrier.

Because biochanin A can be converted to genistein in certain tumour cells (Peterson et al. 1998), we synthesized a novel carboxy derivative of biochanin A, which can serve as a prodrug, and evaluated the oestrogenic and anti-oestrogenic properties of the resulting 6carboxymethyl biochanin A (6CB). 6CB acted similarly to 6CG (Somjen et al. 2002) in vitro and in vivo. 6CB was not capable of inducing transcription via an oestrogen receptor element in MCF7 cells that possess endogeneous ER $\alpha$, but in the presence of oestrogen, $6 \mathrm{CB}$ displayed weak antagonist activity (Fig. 2), in common with 6CG. In addition, 6CG and 6CB, in common with oestrogen, were capable of stimulating DNA synthesis in H295R cells (Fig. 4) and of increasing CK specific activity in these cells. Interestingly, the combination of oestrogen with $6 \mathrm{CB}$ did not have additive or stimulatory effects on CK activity in these cells. Moreover, raloxifene exhibited no stimulatory effect on either DNA synthesis or CK specific activity and did not attenuate oestrogen-, 6CB- or 6CG-driven CK stimulation in $\mathrm{H} 295 \mathrm{R}$ cells, suggesting that the response profile of the SERM raloxifene is different in this cell type.

In in vivo experiments, $6 \mathrm{CB}$ increased $\mathrm{CK}$ activity in rat tissues derived from immature female rats, with the exception of the uterus. Moreover, 6CB, like 6CG and raloxifene, was capable of inhibiting oestrogen-induced CK stimulation in rat tissues (Table 2, 6CB). Collectively, the results suggest that these carboxy derivatives of isoflavones appear to possess a mixed agonistic/ antagonistic character: they increase CK specific activity in several sites in rat tissues in vivo and in vitro, but antagonize oestrogen-induced CK activity in vivo, and partially block the transcriptional activity of oestrogen in MCF7 cells transfected with ERE-luciferase, but not in H295R cells in vitro. This is by no means an unprecedented profile of a SERM. Thus a response profile in one cell type cannot be extrapolated to other cell types.

The presence of a reactive carboxy group in the isoflavone molecule permitted the synthesis of cytotoxic isoflavones. The cytotoxic isoflavone conjugates were prepared by coupling daunomycin via the amino group of the sugar moiety to carboxy derivatives of isoflavones (6CG and 6CB; Fig. 1). The cytotoxicity of these conjugates was tested in H295R cells (Fig. 5a). At low concentrations $(0 \cdot 3-3 \mathrm{nM})$, both conjugates were 10 to 30 times more potent than daunomycin. At $30 \mathrm{nM}$, both conjugates were two to three times more potent than daunomycin. No difference in toxicity was observed between daunomycin and these conjugates at high concentrations (300-
3000 nM; Fig. 5a). In addition, when H295R cells were treated with a combination of 6CG plus daunomycin, the observed cytoxicity was less than that of daunomycin alone over a wide range of concentrations. In contrast, when IEC cells devoid of ER, used as control, were treated with 6CG-Dau conjugate or daunomycin alone, no difference in cytotoxicity was observed between the drug and the conjugate over the range of concentrations tested $(0 \cdot 3-$ $3000 \mathrm{nM}$; Fig. 5b). Whether or not these conjugates recognize a putative membranal ER (unpublished results) and exert part of their effects via a putative membranal ER is currently under investigation.

The clinical management of malignant adrenal tumours (Ng \& Libertino 2003) is difficult at present. Our results suggest that the presence of specific ER recognition sites in some tumour types may be exploited for site-directed chemotherapy using the cytotoxic isoflavone conjugates described in this paper.

\section{Acknowledgements}

We are grateful to Dr H Thole for the generous gift of polyclonal antibody raised against the carboxy terminal of the porcine ER $\alpha$, to Dr B van der Burg for the 3 xERE-TATA-Luc reporter plasmid, and to Dr D McDonnell for the cDNA probe for ER $\alpha$.

\section{References}

Arber N, Sutter T, Miyake M, Kahn SM, Venkatraj VS, Sobrino A, Warburton D, Holt PR \& Weinstein IB 1996 Increased expression of cyclin D1 and the Rb tumor suppressor gene in $\mathrm{c}-\mathrm{K}-\mathrm{ras}$ transformed rat enterocytes. Oncogene 12 1903-1908.

Gazdar AF, Oie HK, Shackleton CH, Chen TR, Triche TJ, Myers CE, Chrousos GP, Brennan MF, Stein CA \& La Rocca RV 1990 Establishment and characterization of a human adrenocortical carcinoma cell line that expresses multiple pathways of steroid biosynthesis. Cancer Research 50 5488-5496.

Gell JS, Oh J, Rainey WE \& Carr BR 1998 Effect of estradiol on DHEAS production in the human adrenocortical cell line, H295R. Journal of the Society for Gynecologic Investigation 5 144-148.

Kohen F, Gayer B, Amir-Zaltsman Y, Ben-Hur H, Thomas E \& Lu LJ 1999 A nonisotopic enzyme-based immunoassay for assessing human exposure to genistein. Nutrition and Cancer 35 96-103.

Kurzer MS \& Xu X 1997 Dietary phytoestrogens. Annual Review of Nutrition 17 353-381.

Mesiano S, Katz SL, Lee JY \& Jaffe RB 1999 Phytoestrogens alter adrenocortical function: genistein and daidzein suppress glucocorticoid and stimulate androgen production by cultured adrenal cortical cells. Journal of Clinical Endocrinology and Metabolism $842443-2448$.

Ng L \& Libertino JM 2003 Adrenocortical carcinoma: diagnosis, evaluation and treatment. Journal of Urology 169 5-11.

Ohno S, Shinoda S, Toyoshima S, Nakazawa H, Makino T \& Nakajin S 2002 Effects of flavonoid phytochemicals on cortisol production and on activities of steroidogenic enzymes in human adrenocortical H295R cells. Journal of Steroid Biochemistry and Molecular Biology 80 355-363.

Peterson TG, Ji GP, Kirk M, Coward L, Falany CN \& Barnes S 1998 Metabolism of the isoflavones genistein and biochanin A in human breast cancer cell lines. American Journal of Clinical Nutrition $\mathbf{6 8}$ 1505S-1511S. 
Sanderson JT, Boerma J, Lansbergen GW \& van den Berg M 2002 Induction and inhibition of aromatase (CYP19) activity by various classes of pesticides in H295R human adrenocortical carcinoma cells. Toxicology and Applied Pharmacology 182 $44-54$.

Somjen D, Kohen F, Jaffe A, Amir-Zaltsman Y, Knoll E \& Stern N 1998 Effects of gonadal steroids and their antagonists on DNA synthesis in human vascular cells. Hypertension 32 39-45.

Somjen D, Amir-Zaltsman Y, Gayer B, Kulik T, Knoll E, Stern N, Lu LJ, Toldo L \& Kohen F 2002 6-Carboxymethyl genistein: a novel selective oestrogen receptor modulator (SERM) with unique, differential effects on the vasculature, bone and uterus. Journal of Endocrinology 173 415-427.

Staels B, Hum DW \& Miller WL 1993 Regulation of steroidogenesis in NCI-H295 cells: a cellular model of the human fetal adrenal. Molecular Endocrinology 7 423-433.

Received 29 July 2003

Accepted 28 August 2003

Made available online as an

Accepted Preprint 2 September 2003 